\title{
Improving our knowledge of rapid geomagnetic field intensity changes observed in Europe between 200 and $1400 \mathrm{AD}$
}

\author{
Miriam Gómez-Paccard a,*, Annick Chauvin ${ }^{\text {b }}$, Philippe Lanos ${ }^{\text {b,c }}$, Philippe Dufresne ${ }^{\text {b,c }}$, Mary Kovacheva ${ }^{\mathrm{d}}$, \\ Mimi J. Hill ${ }^{\mathrm{e}}$, Elisabet Beamud ${ }^{\mathrm{f}}$, Sophie Blain ${ }^{\mathrm{c}}$, Armel Bouvier ${ }^{\mathrm{c}}$, Pierre Guibert ${ }^{\mathrm{c}}$, Archaeological \\ Working Team ${ }^{1}$ \\ a Institut de Ciències de la Terra Jaume Almera, ICTJA-CSIC, Solé i Sabarís s/n, 08028 Barcelona, Spain \\ ${ }^{\mathrm{b}}$ Géosciences-Rennes, UMR 6118, Université de Rennes 1,CNRS, Campus de Beaulieu, Bât. 15, CS 74205, 35042 Rennes, France \\ ' Centre de Recherches en Physique Appliquée à l'Archéologie, UMR 5060, CNRS, Université de Bordeaux 3, France \\ ' NIGGG, BAS, Academician Georgi Bonchev Street, Block 3, 1113 Sofia, Bulgaria \\ e Geomagnetism Laboratory, School of Environmental Sciences, University of Liverpool, Liverpool L69 7ZE, UK \\ ${ }^{\mathrm{f}}$ Laboratori de Paleomagnetisme CCiT UB-CSIC, Institut de Ciències de la Terra Jaume Almera, Solé i Sabarís s/n, 08028 Barcelona, Spain
}

\section{A R T I C L E I N F O}

\section{Article history:}

Accepted 22 August 2012

Editor: P. DeMenocal

Available online 10 October 2012

Keywords:

archaeomagnetism

archaeointensity

secular variation

dipole moment

Thellier

Europe

\begin{abstract}
A B S T R A C T
Available archaeomagnetic data indicate that during the past $2500 \mathrm{yr}$ there have been periods of rapid geomagnetic field intensity fluctuations interspersed with periods of almost constant field strength. Despite Europe being the most widely covered region in terms of archaeomagnetic data the occurrence and the behaviour of these rapid geomagnetic field intensity changes is under discussion and the challenge now is to precisely describe them. The aim of this study is to obtain an improved description of the sharp intensity change that took place in western Europe around $800 \mathrm{AD}$ as well as to investigate if this peak is observed at the continental scale. For this purpose 13 precisely dated early medieval Spanish pottery fragments, four archaeological French kilns and three collections of bricks used for the construction of different French historical buildings with ages ranging between 335 and 1260 AD have been studied. Classical Thellier experiments performed on 164 specimens, and including anisotropy of thermoremanent magnetisation and cooling rate corrections, gave 119 reliable results. The 10 new high-quality mean archaeointensities obtained confirm the existence of an intensity maximum of $\sim 85 \mu \mathrm{T}$ (at the latitude of Paris) centred at $\sim 800 \mathrm{AD}$ and suggest that a previous abrupt intensity change occurred around $600 \mathrm{AD}$. Together with previously published data from western Europe that we deem to be the most reliable, the new data also suggest the existence of two other abrupt geomagnetic field intensity variations during the 12th century and around the second half of the 13th century AD. High-quality archaeointensities available from eastern Europe indicate that very similar geomagnetic field intensity changes occurred in this region. European data indicate that very rapid intensity changes (of at least $20 \mu \mathrm{T} /$ century) took place in the recent history of the Earth's magnetic field. The results call for additional high-quality archaeointensities obtained from precisely dated samples and for a selection of the previously published data if a refined description of geomagnetic field intensity changes at regional scales is to be obtained.
\end{abstract}

(c) 2012 Elsevier B.V. All rights reserved.

\footnotetext{
* Corresponding author. Tel.: +34 934095410; fax: +34 934110012.

E-mail address: mgomezpaccard@ictja.csic.es (M. Gómez-Paccard).

${ }^{1}$ Sonia Gutiérrez-Lloret and Victor Cañavate (Área de Arqueología, Facultad de Filosofía y Letras, Universidad de Alicante, Spain), Christine Oberlin (Centre de datation par le RadioCarbone, Université de Lyon 1, France), Christian Sapin (Laboratoire Artehis, CNRS, UMR 5594, Université de Bourgogne, Dijon, France), Daniel Prigent (Service Départemental de l'Archéologie, CG49, Angers, France), Sébastian Jesset (Service archéologique municipal, Orléans, France), Hervé Pomarèdes (INRAP: Institut national de recherche Archéologique Préventive, Direction interrégionale Méditerranée, Nîmes, France).
}

\section{Introduction}

Unravelling past changes in geomagnetic field intensity is crucial to understand the dynamics of the geodynamo and to investigate the link between solar activity, ${ }^{14} \mathrm{C}$ production, the Earth's magnetic field and climate (e.g., Bard and Delaygue, 2008; Courtillot et al., 2007; Gallet et al., 2005; Muscheler et al., 2007; Snowball and Muscheler, 2007; Wollin et al., 1978). Geomagnetic field reconstructions can be obtained by studying well-dated archaeological material, volcanic rocks or lacustrine and marine sediments. Recently, much effort has been made to recover palaeosecular variation (PSV) of the geomagnetic field in Europe 
over the last millennia (e.g., Genevey et al., 2009; Gómez-Paccard et al., 2006a, 2008; Hervé et al., 2011; Schnepp et al., 2009; Márton, 2010). However, higher resolution intensity records are undoubtedly necessary to improve reconstructions of past geomagnetic field intensity changes (e.g., Gómez-Paccard et al., 2008; Snowball and Muscheler, 2007; Tema et al., 2012).

The need for a greater number of globally distributed palaeointensity data is also highlighted by the inconsistencies observed between global geomagnetic field models and data even for recent times (Finlay, 2008; Genevey et al., 2009; Gubbins et al., 2006; Hartmann et al., 2011; Jackson et al., 2000; Suttie et al., 2011). Another important consideration for geomagnetic field reconstructions is the reliability of the palaeointensity data (Chauvin et al., 2000). In this sense objective selection criteria based on palaeomagnetic considerations are clearly needed in order to assess the reliability of palaeointensities (Chauvin et al., 2000; Genevey et al., 2008; Gómez-Paccard et al., 2008; Schnepp et al., 2009). On the other hand, the ages uncertainties (from few years when historical records are available up to some centuries) and errors associated with intensity determinations indicate that several data per century are necessary if a precise description of geomagnetic field intensity changes wants to be obtained (Gómez-Paccard et al., 2006c). This multi-site approach has been widely applied for the construction of PSV directional curves (e.g., Gallet et al., 2002; Gómez-Paccard et al., 2006b; Schnepp and Lanos, 2005; Tema et al., 2006; Zananiri et al., 2007).

Available western European data indicate that during the past $2500 \mathrm{yr}$ there have been periods of rapid intensity fluctuations, such as the one observed around $800 \mathrm{AD}$, interspersed with periods of little change, as seen during Roman times (Chauvin et al., 2000; Gallet et al., 2003, 2009a; Genevey and Gallet, 2002; Genevey et al., 2009; Gómez-Paccard et al., 2008). The challenge now is to precisely describe these rapid intensity changes and to understand how such behaviour can arise (Gallet et al., 2009b). One of the periods with a strikingly poor data coverage is the period between 500 and $1000 \mathrm{AD}$ for which only six archaeointensities are available for western Europe (Catanzariti et al., 2012; Gallet et al., 2009a; Genevey and Gallet, 2002; Kovacheva et al., 2009a). Based on the available French data an intensity peak around $800 \mathrm{AD}$ followed by a strong decrease of about 30\% with associated rate of change as fast as $\sim 7 \mu \mathrm{T} /$ century has been previously identified (Genevey and Gallet, 2002).

In order to further constrain field strength behaviour around $800 \mathrm{AD}$, new archaeointensities have been obtained from the study of 13 precisely dated early medieval Spanish pottery fragments with ages ranging from 750 to 900 AD. In addition, four French kilns and three collections of bricks used in the construction of historical French buildings with ages ranging between 335 and 1260 AD have been studied. The new data, together with a selection of previous archaeointensities, enable an improved description of geomagnetic field intensity changes that took place in western Europe between the 3rd and the 14th centuries AD. Finally, the selected western European data are compared with high-quality data from eastern Europe and with geomagnetic field models' results.

\section{Archaeological setting and dating}

\subsection{Early medieval Spanish pottery fragments}

Thirteen pottery fragments collected from El Tolmo de Minateda archaeological site (TM in Fig. 1) have been studied. The archaeological/historical context together with numismatic evidence and stratigraphic constraints between the different stratigraphic units where the material was found allows the

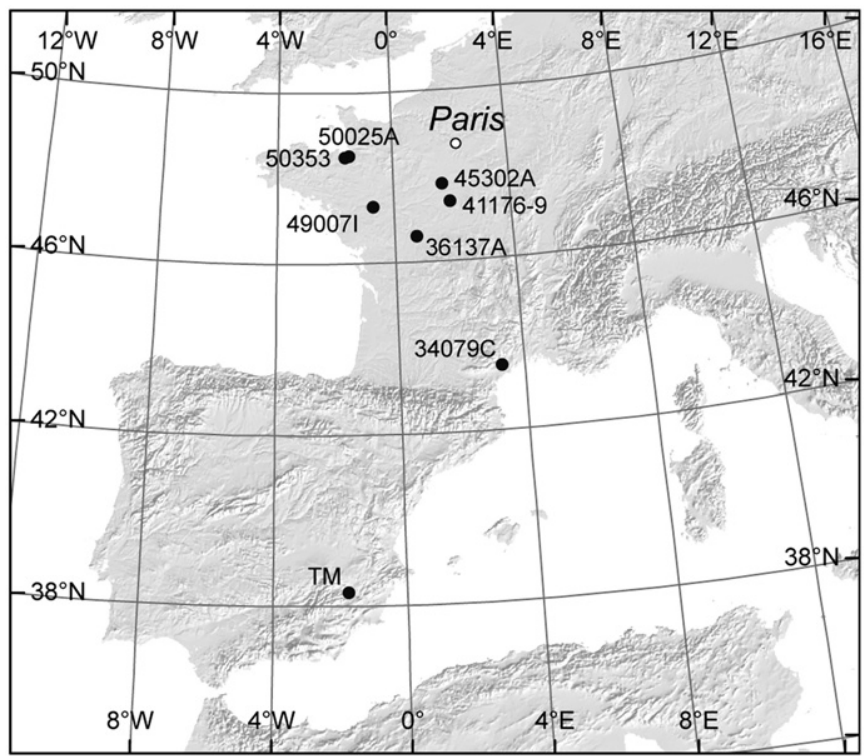

Fig. 1. Location of the archaeological/historical sites where the archaeomagnetic material was recovered. The reference location (Paris) where the archaeointensity data have been relocated is also shown.

precise dating of the studied ceramic fragments (see Table 1 and Supplementary material: Section 1 and Table S1, for further details).

\subsection{Bricks used for the construction of historical French buildings}

The early medieval period in France (between 400 and 1100 $\mathrm{AD}$, approximately) is not well known mainly due to the restricted number of buildings from this period still standing. Indeed most of the pre-Romanesque buildings have been reused, abandoned and savaged. Only structures constructed using nonperishable materials (e.g., stones or bricks), such as religious constructions, remained standing. Three historical buildings from western France (Fig. 1) have been studied from this period: the collegial church St. Martin located in Angers (site 49007I), the Notre-Dame-Sous-Terre church (site 50353) located in the MontSaint-Michel abbey and the keep of the castle of Avranches (site 50025A).

In order to investigate the chronology of these sites a multidisciplinary approach was followed, involving experts of different dating techniques (thermoluminescence TL and radiocarbon ${ }^{14} \mathrm{C}$ ), art historians and archaeologists. TL was used to date the last heating of the bricks used for the construction of the historical buildings, which is in fact the date of the manufacture of the bricks. TL dating and archaeointensity analyses were performed on subsamples from the same unoriented cores, which were drilled directly from different bricks. Radiocarbon analyses were conducted on charcoals found within mortars. The final dates ascribed for the French buildings (Table 1) were obtained using a Bayesian statistical approach for chronological modelling (Lanos, 2004). This approach takes into account all the chronological information available for each site (archaeological and historical constraints and ${ }^{14} \mathrm{C}$ and $\mathrm{TL}$ dating results) and assumes that the dates given by the different methods are related to the same event (i.e. the last firing of the set of bricks) with some errors that are modelled with a Gaussian prior density with unknown variance (Lanos, 2001, 2004; RenDateModel: http://www.projetplume.org/fr/relier/rendatemodel; Sapin et al., 2008). A Monte Carlo Markov Chain computation (Gilks et al., 1996) is performed over a large range of variances $[0,+\infty]$, yielding to a posterior 
Table 1

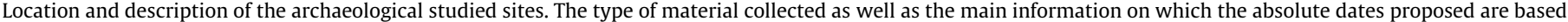

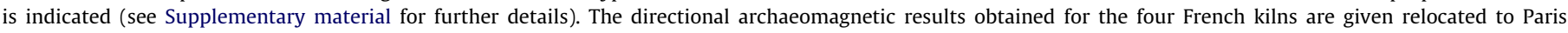

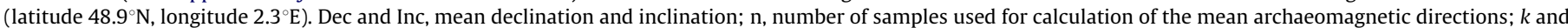
$\alpha_{95}$, precision parameter and $95 \%$ confidence level of mean archaeomagnetic directions.

\begin{tabular}{|c|c|c|c|c|c|c|}
\hline $\begin{array}{l}\text { Archaeological site } \\
\text { (material) }\end{array}$ & $\begin{array}{l}\text { Lat. } \\
\text { (deg.) }\end{array}$ & $\begin{array}{l}\text { Long. } \\
\text { (deg.) }\end{array}$ & Lab. code & Dating method & $\begin{array}{l}\text { Archaeomagnetic } \\
\text { direction (relocated to } \\
\text { Paris) }\end{array}$ & $\begin{array}{l}\text { Dating at } 95 \% \\
\text { confidence level } \\
\text { (yr. AD) }\end{array}$ \\
\hline Clermont- l'Hérault (kiln) & $43.63 N$ & $3.43 \mathrm{E}$ & $34079 C$ & $\begin{array}{l}\text { Archaeological context: end of Roman } \\
\text { period }[300,600]+\text { one }{ }^{14} \mathrm{C} \text { from } \\
\text { neighbouring kiln }\end{array}$ & $\begin{array}{l}\text { Dec }=0.4^{\circ}, \text { Inc }=62.5^{\circ} \\
n=20, \alpha_{95}=1.1^{\circ}, k=875\end{array}$ & {$[335,540]$} \\
\hline Pierrefitte-sur-Sauldre (kiln) & $47.52 \mathrm{~N}$ & $2.10 \mathrm{E}$ & $41176-9$ & $\begin{array}{l}\text { Archaeological context: local ceramics } \\
{[600,650]+\text { one }{ }^{14} \mathrm{C} \text { date for the kiln }}\end{array}$ & $\begin{array}{l}\text { Dec }=6.1^{\circ}, \text { Inc }=70.2^{\circ} \\
n=21, \alpha_{95}=1.1^{\circ}, k=791\end{array}$ & {$[590,655]$} \\
\hline Néons-sur-Creuse (kiln) & $46.74 \mathrm{~N}$ & $0.91 \mathrm{E}$ & $36137 \mathrm{~A}$ & $\begin{array}{l}\text { Archaeological context: Early Middle Age } \\
{[600,900]}\end{array}$ & $\begin{array}{l}\text { Dec }=5.3^{\circ}, \text { Inc }=72.3^{\circ} \\
n=14, \alpha_{95}=1.6^{\circ}, k=550\end{array}$ & {$[600,900]$} \\
\hline Saran, Zac des Vergers (kiln) & $47.95 \mathrm{~N}$ & $1.88 \mathrm{E}$ & $45302 \mathrm{~A}$ & $\begin{array}{l}\text { Archaeological context: local ceramics } \\
{[675,725]}\end{array}$ & $\begin{array}{l}\mathrm{Dec}=3.0^{\circ}, \text { Inc }=73.7^{\circ} \\
n=13, \alpha_{95}=1.9^{\circ}, \mathrm{k}=412\end{array}$ & {$[675,725]$} \\
\hline $\begin{array}{l}\text { Angers, Collegial church St. } \\
\quad \text { Martin (bricks in buildings) }\end{array}$ & $47.47 \mathrm{~N}$ & $0.55 W$ & 49007I & $\begin{array}{l}\text { Five thermoluminescence results }+ \text { one } \\
{ }^{14} \mathrm{C} \text { date }\end{array}$ & & {$[810,910]$} \\
\hline $\begin{array}{l}\text { Mont-Saint-Michel, Notre- } \\
\text { Dame-Sous-Terre church } \\
\text { (bricks in buildings) }\end{array}$ & $48.63 \mathrm{~N}$ & $1.5 \mathrm{~W}$ & 50353 & $\begin{array}{l}\text { Eight thermoluminescence results }+ \text { three } \\
{ }^{14} \mathrm{C} \text { dates }\end{array}$ & & {$[900,990]$} \\
\hline $\begin{array}{l}\text { Avranches, Castle of Avranches } \\
\quad \text { (bricks in buildings) }\end{array}$ & $48.68 \mathrm{~N}$ & $1.35 \mathrm{~W}$ & $50025 \mathrm{~A}$ & Five thermoluminescence results & & {$[1100,1260]$} \\
\hline \multirow[t]{14}{*}{$\begin{array}{l}\text { Albacete, Tolmo de Minateda } \\
\quad \text { (ceramic fragments) }\end{array}$} & $38.48 \mathrm{~N}$ & $1.61 \mathrm{~W}$ & TM & Historical/archaeological constraints & & $\begin{array}{l}\text { Attributed ages } \\
\text { (yrs AD) }\end{array}$ \\
\hline & & & TM-02 & & & {$[800,850]$} \\
\hline & & & TM-03 & & & {$[750,800]$} \\
\hline & & & TM-04 & & & {$[775,800]$} \\
\hline & & & TM-05 & & & {$[750,800]$} \\
\hline & & & TM-06 & & & {$[750,800]$} \\
\hline & & & TM-07 & & & {$[750,800]$} \\
\hline & & & TM-08 & & & {$[750,800]$} \\
\hline & & & TM-09 & & & {$[750,800]$} \\
\hline & & & TM-10 & & & {$[750,800]$} \\
\hline & & & TM-11 & & & {$[750,800]$} \\
\hline & & & TM-12 & & & {$[825,875]$} \\
\hline & & & TM-13 & & & {$[775,800]$} \\
\hline & & & TM-14 & & & {$[850,900]$} \\
\hline
\end{tabular}

dating density from which an interval at a given confidence level can be determined. In this study we used the 95\% confidence level. The final dates ascribed for each site are described in Table 1 (see Supplementary material: Section 2 and Table S2 for further details).

\subsection{French archaeological kilns}

Four mediaeval kilns were sampled at Clermont-l'Hérault (site 34079C), Pierrefitte-sur-Sauldre (site 41176-9), Néon-sur-Creuse (36137A) and Saran (45302A) (Fig. 1). At Néons-sur-Creuse a hearth of a $1 \mathrm{~m}$ diameter kiln was excavated, while larger pottery kilns (up to $4 \mathrm{~m}$ length on $2 \mathrm{~m}$ wide) were recovered in Saran, Pierrefitte-sur-Sauldre and Clemont-l'Hérault. Kilns 36137A and 45302 were dated by archaeological constraints (Supplementary material: Section 3 for further details). Two ${ }^{14} \mathrm{C}$ results obtained from charcoal samples found during the excavations of sites $34079 \mathrm{C}$ and 41176-9 were also obtained. The Bayesian approach was used to date the last firing of kilns $34079 \mathrm{C}$ and $41176-9$ by combination of the archaeological information and the calibrated ${ }^{14} \mathrm{C}$ results (Supplementary material: Section 3 ).

Additionally, mean directions of the characteristic remanent magnetisation (ChRM) of each kiln were derived from thermal demagnetisation experiments performed on one specimen per core and from principal component analysis (Kirschvink, 1980) and Fisher statistics (Fisher, 1953). Experiments were performed at the Géosciences-Rennes laboratory and were corrected for the effect of the thermoremanent magnetisation (TRM) anisotropy. Only one component of magnetisation was observed on samples from sites 34079C, 36137A and 41176-9, corresponding to median destructive temperatures (MDT) between 300 and $510^{\circ} \mathrm{C}$. Precise $\left(\alpha_{95}<2^{\circ}\right)$ mean site directions for kilns 34079C, 36137A and 41176-9 were calculated using 20, 14 and 21 samples, respectively (Table 1 ). The mean directions were relocated to Paris using the Virtual Geomagnetic Pole (VGP). A secondary component of magnetisation removed at temperatures between 300 and $460{ }^{\circ} \mathrm{C}$ was observed on 14 samples from kiln 45302A. On these samples, the high temperature component has no preferential direction in in situ coordinates suggesting that it corresponds to the heating of the tiles (see Section 3.1) during their manufacture. The other 13 samples (corresponding to MDT between 300 and $450{ }^{\circ} \mathrm{C}$ ) show a well-defined single component of magnetisation and were used to derive mean direction for kiln 45302A. The ChRM directions obtained (Table 1) are in close agreement with the directions described by the French PSV curve (Gallet et al., 2002) for the dates proposed for the abandonment of 
each kiln (Table 1). The directional analysis gives further support to the chronological framework proposed. However, it should be noted that archaeomagnetic dating has not been used to refine the final ages ascribed for each kiln.

\section{Methodology}

\subsection{Sample preparation}

Four specimens of about $1 \mathrm{~cm} \times 1 \mathrm{~cm}$ per pottery fragment were prepared for the Thellier experiments. The 52 specimens obtained were packed into salt pellets in order to treat them as standard palaeomagnetic cubes (Pick and Tauxe, 1993). The remaining material was kept for microwave and rock magnetic experiments. Two mini cores per fragment $(5 \mathrm{~mm}$ diameter and 2-5 mm long) were drilled for use with the $14 \mathrm{GHz}$ microwave and Tristan magnetometer system (Stark et al., 2010) at Liverpool University.

Standard palaeomagnetic cores were drilled from bricks in the Notre-Dame-Sous-Terre church (90 cores), the Collegial church St. Martin (166 cores) and the castle of Avranches (10 cores). Large oriented block samples were taken from tiles (sites 45302A, 41176-9, 36137A) and bricks (sites 34079C) making up the sides of the four studied medieval kilns. The blocks were oriented by placing plaster hats on the top surface (levelled horizontal using a bubble) and oriented using sun and magnetic compasses. A circular saw was used to remove the block samples that were drilled at the laboratory giving standard oriented palaeomagnetic cores from each block sample.

\subsection{Magnetic measurements}

Classical Thellier experiments were conducted at the palaeomagnetic laboratories of the Institute of Earth Sciences Jaume Almera (Barcelona, Spain) and Géosciences-Rennes (Rennes, France). The thermal treatment was conducted using MMTD-80 (Magnetic Measurements) furnaces and the magnetisation measurements were performed using a SRM755R (2G Enterprises) three-axes cryogenic superconducting rock, Agico JR5 and Molspin spinner magnetometers. Bulk susceptibilities $(\chi)$ were also measured with a Kappabridge KLY-2 (Geofyzica Brno) susceptibility bridge using a field of $0.1 \mathrm{mT}$ at a frequency of $470 \mathrm{~Hz}$ and with a Bartington susceptibility metre. The original Thellier method (Thellier and Thellier, 1959) with regular partial thermoremanent magnetisation (pTRM) checks was used to estimate archaeointensities. Experiments were carried out in air and a laboratory field of 40,50 or $60 \mu \mathrm{T}$ was applied. At each temperature step, the samples were first heated and cooled with the laboratory field applied along their $Z$-axis and second, were heated and cooled with the laboratory field applied in the opposite sense. The experimental procedures followed are the same as in our previous work (Gómez-Paccard et al., 2006c, 2008). Biases due to TRM anisotropy in some archaeological material such as bricks, tiles or ceramics should be taken into account if accurate archaeointensities are to be obtained (Chauvin et al., 2000; Genevey et al., 2008). Therefore the TRM anisotropy tensor was determined for each specimen and used to correct archaeointensities. Another important consideration in archaeointensity studies is the cooling rate dependence of TRM acquisition. Although the real cooling time experienced by the different pottery fragments, kilns or bricks is not exactly known, a slow cooling time of about $24 \mathrm{~h}$ was used during the cooling rate protocol carried out in the laboratory. A cooling rate correction factor was then obtained for each specimen if no major evolution of TRM acquisition capacity was observed during the entire procedure, which includes four additional heating-cooling steps (Gómez-Paccard et al., 2006c).

Several criteria were used to select acceptable Thellier experiments at the specimen level. pTRM checks have been considered positive if, at a given temperature, the difference between the original PTRM and the pTRM check does not exceed $10 \%$ of the total TRM acquired. We fixed a limit of $45 \%$ for the fraction of the initial natural remanent magnetisation (NRM) involved for archaeointensity determinations ( $f$ parameter; Coe et al., 1978). Only linear NRM-TRM diagrams corresponding to well defined straight lines going to the origin in the Zijderveld diagrams have been considered. The maximum angular deviation (MAD; Kirschvink, 1980) and the deviation angle (DANG; Pick and Tauxe, 1993) have to be lower than $5^{\circ}$. However, it should be noted that the DANG is not always sufficient criteria to detect mineralogical changes or multidomain behaviour if the direction of the NRM and the magnetic laboratory field are subparallel during Thellier experiments (Hervé et al., 2011).

Microwave experiments were also conducted on selected ceramic fragments as an additional check on repeatability and reliability of the more extensive Thellier experiments. One specimen per fragment underwent microwave demagnetisation in order to determine remanence characteristics and the powers needed to demagnetise the samples. The sister specimens then underwent the Coe variant of the Thellier method (Coe, 1967) incorporating microwave pTRM ( $\left.\mathrm{pT}_{\mathrm{M}} \mathrm{RM}\right)$ and $\mathrm{pT}_{\mathrm{M}} \mathrm{RM}$ tail checks generally every second step. Additional $\mathrm{pT}_{\mathrm{M}} \mathrm{RM}$ checks back to the lowest microwave power were also carried out at various higher powers. The applied field of 70 or $75 \mu \mathrm{T}$ was imparted along the NRM direction in order to minimise anisotropy and multidomain effects (e.g., Biggin, 2010).

\section{Rock magnetism}

\subsection{Q ratios}

Initial NRM intensities and susceptibilities have been measured for all the specimens (Fig. 2; Supplementary material: Table S3). The Koenigsberger ratios Q (defined as the ratio of NRM to the induced magnetisation using a field of $40 \mathrm{~A} / \mathrm{m}$ ) range between 1 and 1000. Some of the material analysed (some TM ceramic fragments) acquired a weak partial TRM with Q values lower than

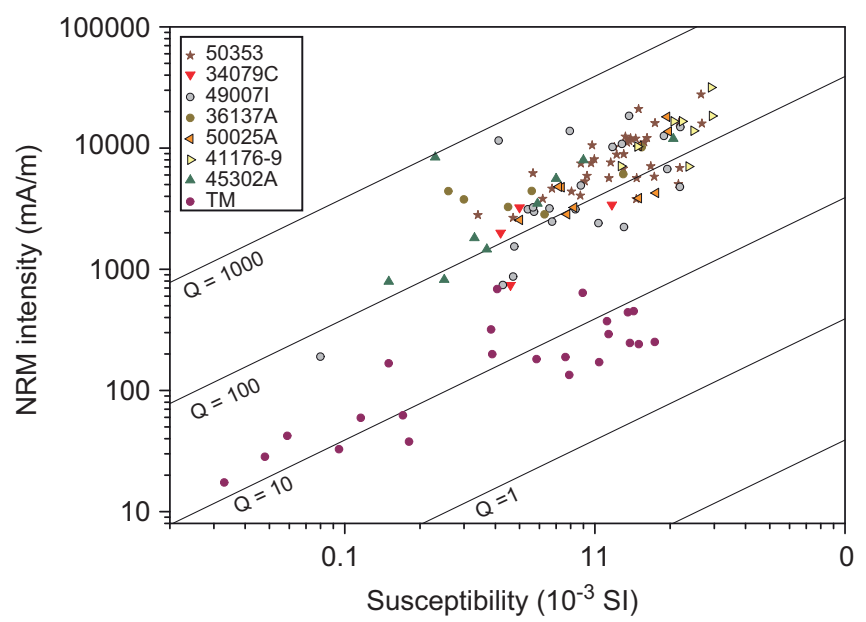

Fig. 2. Intensity of the natural remanent magnetisation (NRM) versus bulk susceptibility. For the specimens derived from the ceramic fragments recovered at El Tolmo de Minateda (TM) these parameters have been normalised by the weight. Black lines indicate constant Koenigsberger ratios (Q). 
10. The other specimens (from kilns, bricks and the remaining TM samples) show $\mathrm{Q}$ between 10 and 1000 . This indicates a strong TRM acquired during the manufacture of the bricks and ceramics or during the last use of the kilns.

\subsection{Spanish pottery fragments}

Rock magnetic experiments of ceramic fragments were carried out using a Variable Field Translation Balance at the University of Liverpool. Acquisition of isothermal remanent magnetisation (IRM), back-field coercivity, hysteresis loops and magnetisation versus temperature experiments were carried out on small pieces ( $\sim 100 \mathrm{mg}$ ) from each fragment. Samples TM-03, 05, 06, 07, 08, 09 and 11 are dominated by a low coercivity phase as evidenced by saturation of the IRM curves and closure of the hysteresis loops (Fig. 3a). The rest of the samples also contain a higher coercivity phase as evidenced by hysteresis loops that do not close and IRM curves that do not saturate (Fig. 3b). Wasp waisted hysteresis loops indicate the presence of these two phases. All samples (apart from TM-03) are dominated by a single Curie temperature ranging between 500 and $550{ }^{\circ} \mathrm{C}$ consistent with an impure magnetite phase. After heating to $700{ }^{\circ} \mathrm{C}$ all samples show a reduction in magnetisation on cooling, suggesting oxidation of magnetite or maghaemite to haematite. The Curie curve for sample TM-03 (not shown) indicates creation of a new magnetic phase during heating at around $560{ }^{\circ} \mathrm{C}$ with a Curie temperature of $660{ }^{\circ} \mathrm{C}$. On cooling this phase is no longer present, with the Curie temperature of the cooling curve around $580{ }^{\circ} \mathrm{C}$ (pure magnetite).

\subsection{French kilns and bricks used for the construction of historical} French buildings

IRM acquisition curves were performed with an ASC pulse magnetiser, and alternating field (AF) demagnetisation was conducted with a Schonstedt GSD1. An Agico KLY3 and a CS-3 furnace were used for Curie experiments ( $K-T$ curves). Measurements of the remanent magnetisation were performed with an Agico JR5 magnetometer. All the experiments were carried out at the Géosciences-Rennes and Sofia palaeomagnetic laboratories.

Samples of tiles and bricks from kilns are characterised by Curie temperatures (TC) between 565 and $590{ }^{\circ} \mathrm{C}$ (Fig. 4a), i.e. very close to the $T c$ of magnetite. Only for two samples $T c$ 's close to $610{ }^{\circ} \mathrm{C}$ were observed (samples 41176-6 and 45302A-12), suggesting some highly oxidised magnetic mineral, like stable maghemite. $K-T$ curves are most of the time reversible (Fig. 4a), in agreement with the thermal stability of magnetic minerals observed during the Thellier experiments (see below). Typical Median Destructive Fields (MDF) between 15 and $25 \mathrm{mT}$ indicate low coercivity ferromagnetic grains. Saturation of the remanence

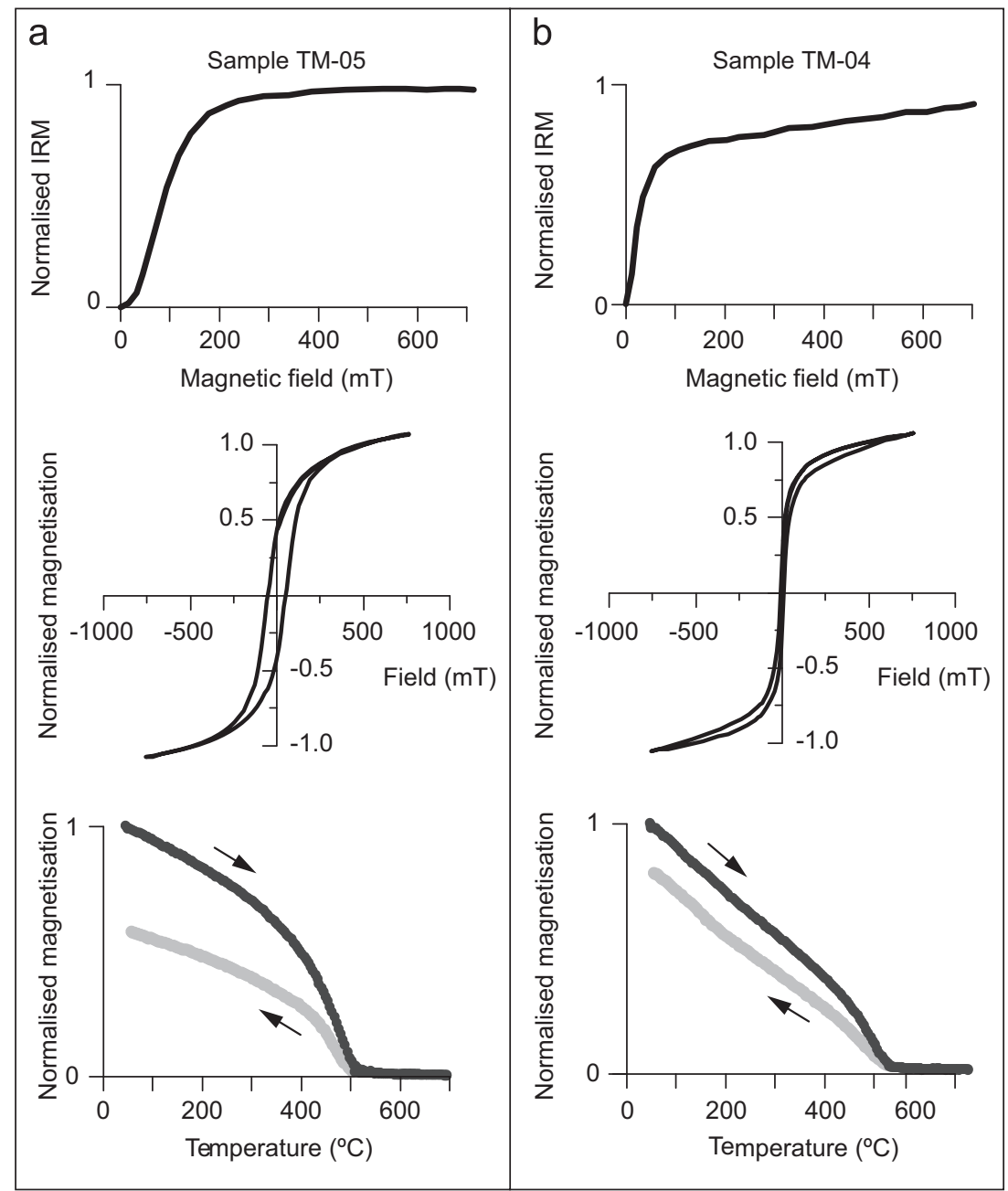

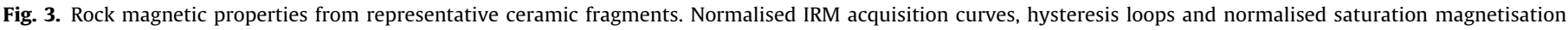

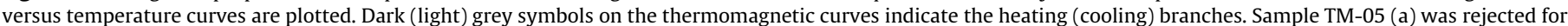
archaeointensity determinations and sample TM-04 (b) provided suitable archaeointensity results for two specimens. 

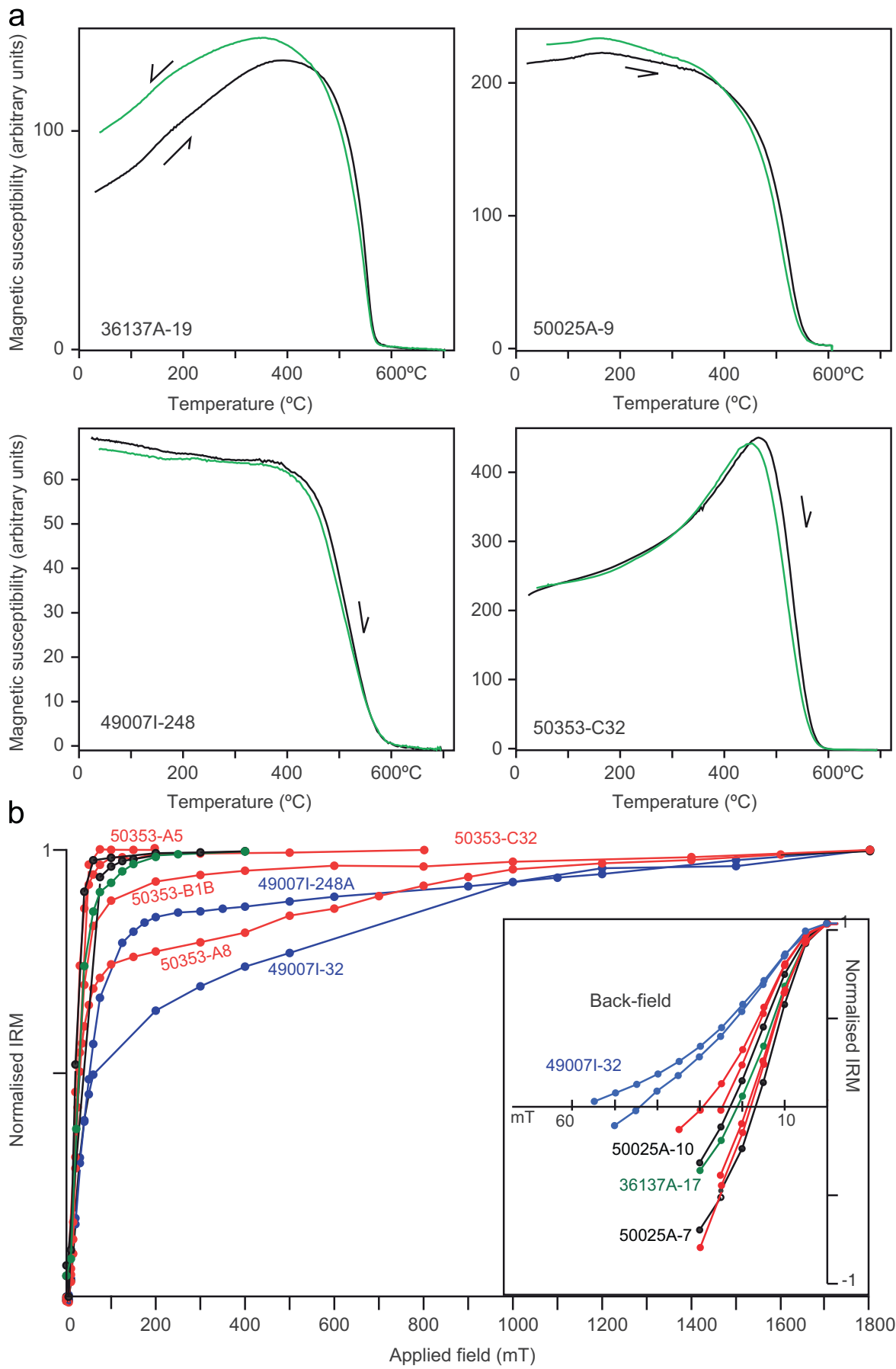

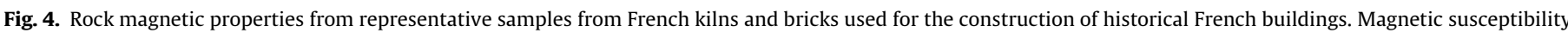
versus temperature curves (a), and isothermal remanent magnetisation (IRM) acquisition curves and back-field IRM curves (b).

is reached at between 200 and $250 \mathrm{mT}$ while coercivity of remanence (Hcr) and saturated remanent magnetisation (Jrs) are close to $20 \mathrm{mT}$ and $3.5 \mathrm{~A} / \mathrm{m}$, respectively (Fig. $4 \mathrm{~b}$ ). The presence of multidomain grains (MD) was tested on 16 samples, following the approach proposed by Shcherbakova et al. (2000). A pTRM was given between $300{ }^{\circ} \mathrm{C}$ and room temperature before to be demagnetised between the same temperature interval. The intensity of the pTRM tail is between $9 \%$ and $0.5 \%$ of the pTRM suggesting that the magnetic grains carrying the TRM are single domain (SD) or pseudo SD grains (Shcherbakova et al., 2000).

Samples from bricks in buildings are characterised by $T c^{\prime}$ 's between 505 and $570{ }^{\circ} \mathrm{C}$, with reversible $K-T$ curves (Fig. 4a). MDF ranges from 16 to $23 \mathrm{mT}$ and $\mathrm{Hcr}$ between 18 and $55 \mathrm{mT}$. Strong values of Jrs are obtained, between 48 and $242 \mathrm{~A} / \mathrm{m}$. On some samples IRM saturation is not reached until $1000 \mathrm{mT}$ (e.g., 50353A8 and 49007I-248A, 49007I-32 in Fig. 4b). However, these samples have $T c^{\prime}$ 's between 510 and $560{ }^{\circ} \mathrm{C}$. All these characteristics indicate that the principal magnetic carriers are slightly substituted magnetites. Haematite was never observed. Despite no hysteresis measurement were performed for these samples, the high success rate and the linearity of the NRM-TRM diagrams over a large temperature interval during the Thellier experiments (see Section 5) suggest that magnetic grains carrying the TRM are SD grains. 

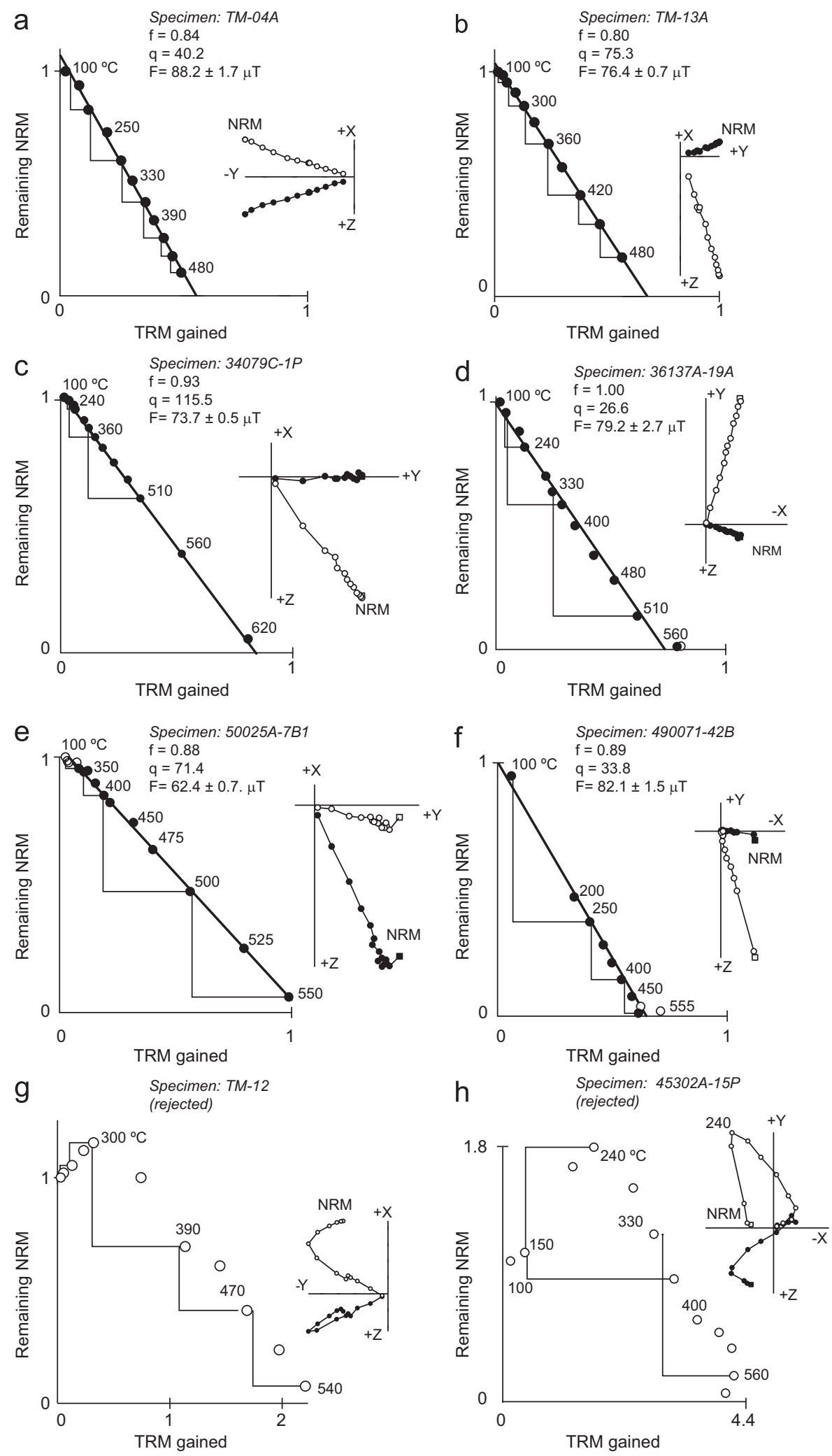

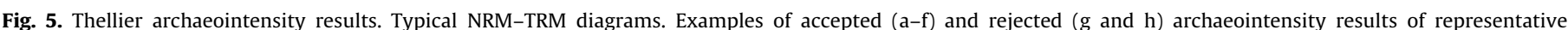

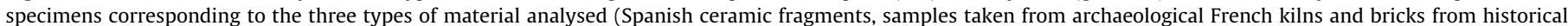

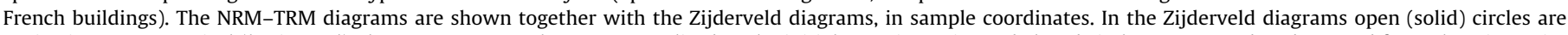

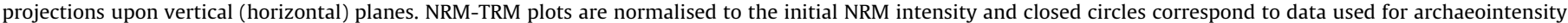
determinations. The estimated archaeointensity (F), the NRM fraction used (f) and the corresponding quality factor (q) are indicated. 


\section{Results: archaeointensity determination}

\subsection{Spanish pottery fragments}

\subsubsection{Thellier experiments}

The Thellier experiments were attempted on 52 specimens. The specimens are characterised by NRM intensities lower than $7 \times 10^{-2} \mathrm{~A} / \mathrm{mg}$ and susceptibilities lower than $10^{-3} \mathrm{SI}$ units $/ \mathrm{g}$ (Supplementary material: Table S3). Nine to fifteen steps were performed between $100{ }^{\circ} \mathrm{C}$ and the maximum temperature applied, which varies from 480 to $590{ }^{\circ} \mathrm{C}$. Two types of behaviour have been observed. Specimens from samples TM-02, 03, 04, 06, 07, 09, 13 and 14 showed a well-defined straight line going towards the origin of the Zijderveld plots after removal of a very weak secondary component of magnetisation during the first temperature steps. This characteristic component likely corresponds to the TRM acquired during the manufacture of the pottery fragments. The maximum unblocking temperatures range between 480 and $540{ }^{\circ} \mathrm{C}$, which is in agreement with the impure magnetite-like phase observed in the rock magnetic experiments. For these specimens linear NRM-TRM diagrams have been observed (Fig. 5a and b). Specimens from samples TM-05, 08, 10, 11 and 12 show a more complex behaviour, with two clear components of magnetisation in the Zijderveld diagrams (e.g., Fig. 5g). In order to only consider the most reliable archaeointensities we discarded the estimations based on these samples.

The 23 accepted archaeointensity determinations which satisfied the selection criteria are listed in Supplementary material: Table S3. The NRM fraction used for archaeointensity determination ranges between 0.46 and 0.95 corresponding with quality factors $q$ values between 13.6 and 75.3. No control of the exact position of the different specimens inside the salt pellets was possible. Therefore, no inferences about the direction of the principal axes of the TRM anisotropy tensor can be done. However, differences between uncorrected and TRM anisotropy corrected values can be very important in this kind of material (Chauvin et al., 2000) and must be taken into account. For the majority of the specimens, differences between the uncorrected and TRM anisotropy corrected values are lower than 30\% (Fig. 6a). For specimens TM-06A, 06B, 03D and 14A differences between the uncorrected and corrected archaeointensities are higher (Supplementary material: Table S3). As in our previous work (Gómez-Paccard et al., 2006c, 2008) archaeointensities have been corrected when the cooling rate correction factor obtained is bigger than the estimated magnetic alteration that took place during the cooling protocol (Supplementary material: Table S3). In general, the cooling rate correction factors applied (Fig. 6b) are not very high with a maximum value of $\sim 7 \%$. From the 52 specimens analysed only 23 archaeointensity determinations have been accepted, showing the difficulty to obtain reliable intensities in more than $50 \%$ of the analysed specimens. However. all the archaeointensities retained correspond to high-quality NRM-TRM diagrams and have been corrected for TRM anisotropy and cooling rate effects. In order to further investigate reliability and consistency of the results obtained, microwave experiments were carried out on selected samples.

\subsubsection{Microwave experiments}

The scarcity of material from samples TM-03, 06 and 08 coupled with their low magnetisation meant that microwave experiments were not pursued for these fragments. Microwave demagnetisation on the remaining fragments demonstrates that a primary component of remanence can be isolated in all cases. A small secondary component of magnetisation is also present. Consistent with the thermal results, samples TM-11 and 12 have more complicated behaviour with an additional lower blocking spectra component of remanence. Sample TM-10, however, did not exhibit this behaviour in contrast to the Thellier results and the sister sample used for the archaeointensity experiment. Sample TM-05 revealed a large secondary component of magnetisation during demagnetisation. However, this was not present in the sister mini core used for the archaeointensity experiment. The secondary component of remanence, when present, does not seem to be homogenously distributed throughout the fragments. This could be explained by the large size (several $\mathrm{cm}$ ) of some of the pottery fragments. However, it is worth noticing that this is generally not observed in Thellier results where very similar behaviour is observed in sister specimens analysed per fragment.

Microwave archaeointensity results are summarised in Table S4 and successful examples shown in Fig. S1 of Supplementary material. Using the same acceptance criteria as for the Thellier experiments five of the eight fragments dominated by a single component of remanence were accepted. Sample TM-12 did not yield a successful result (failure of a pTRM check) consistent with the Thellier study. In contrast to the Thellier study which gave acceptable results for samples from fragment TM-09, pTRM checks failed during the microwave experiment. The microwave
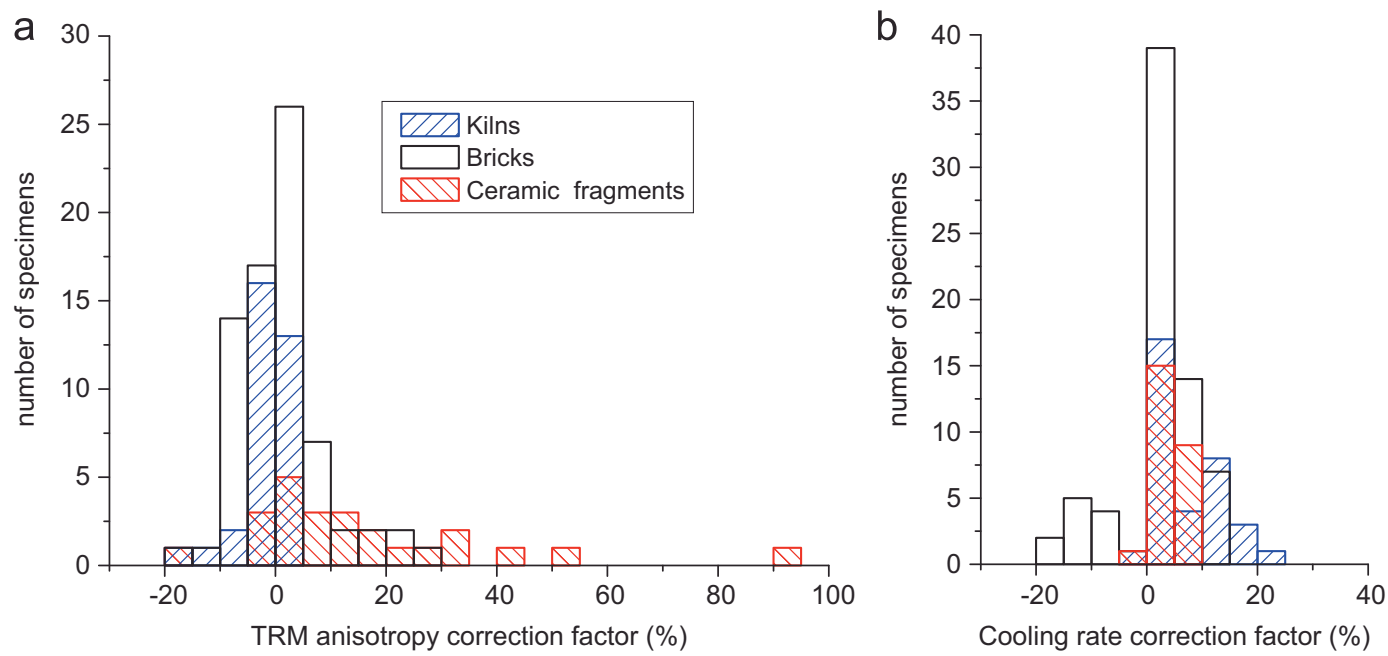

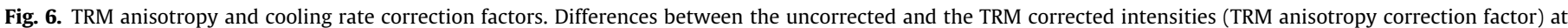
specimen level (a), and cooling rate correction factor applied to archaeointensity determinations (b). Each kind of material analysed is plotted separately. 
experiment on sample TM-04 failed due to the experiment having to be abandoned before complete demagnetisation (low $\mathrm{f}$ factor). It was not possible to obtain archaeointensity estimates from samples TM-10 and 11 which contained significant secondary components of remanence.

The microwave archaeointensities can be compared to the Thellier results. Cooling rate corrections have not been attempted, thus microwave results are compared to the TRM anisotropy corrected Thellier results. Microwave results from samples TM-07 and 14 are within the range obtained with the Thellier method (differences between the two methods are less than 4\%) whereas the microwave result from TM-02 is $13 \%$ higher than the Thellier derived mean. A significant discrepancy is found for TM-13 with the microwave result nearly $30 \%$ higher than the mean of the Thellier estimates. There is no immediately obvious reason for this anomalously high result and further study would be necessary to see if the microwave result is repeatable. We do note, however, that TM-13 does yield the highest archaeointensity estimate in classical Thellier experiments. As only one experiment has been performed per fragment and more experiments are needed in order to confirm the microwave results, these data have not been used in order to recover past archeointensities.

\subsection{French kilns and bricks used for the construction of historical French buildings}

Thellier experiments were attempted on 112 specimens, 96 of them gave reliable results. This high success rate shows the excellent physical and chemical stability of the magnetic minerals contained in the kilns and brick samples. This is in agreement with the magnetic results described in Section 4. All accepted results correspond to high-quality NRM-TRM diagrams related to very well-defined single components of magnetisation going through the origin (Fig. $5 \mathrm{c}-\mathrm{f}$ ). Maximum unblocking temperatures between 480 and $620^{\circ} \mathrm{C}$ were observed. The rejected specimens showed a more complex behaviour with two components of magnetisation (e.g., Fig. 5h) and/or alteration of the magnetic mineralogy during the Thellier experiments.

TRM anisotropy and cooling rate effects upon TRM intensity have been also investigated in these materials (Fig. 6; Supplementary material: Table S3; Kovacheva et al., 2009b). As expected, a low TRM anisotropy effect upon archaeointensities was found for the kilns, for which very low differences between uncorrected and TRM corrected intensities were generally obtained (Fig. 6a). This effect is more important for the bricks with differences reaching values up to $26 \%$. The majority of the specimens (from kilns or bricks) gave low cooling rate correction factors (less than 10\%). However, in some cases these factors are bigger reaching values up to $25 \%$ (Fig. 6b).

\section{Discussion}

\subsection{New archaeointensity data for western Europe}

Supplementary material: Table S3 summarises the results obtained at specimen level for the ceramic fragments. In general, archaeointensities derived from sister specimens from the same fragment are very consistent (e.g., TM-02A, 02B and 02C). However, some important differences are also observed (e.g., TM-03B and 03D), indicating that several specimens per fragment must be studied. Therefore, we retained only mean intensities calculated using at least two specimens per fragment. Additionally, maximum values of $10 \%$ around the means were accepted. Eight fragment-mean intensities satisfied these criteria (TM-02, 03, 04, 06, 07, 09, 13 and 14) and were calculated considering the weighting factor proposed by Prévot et al. (1985). Fragmentmean intensities are generally well defined with standard deviations of less than $8 \%$ for six of the eight fragments. In general, the results are very consistent for fragments which correspond to the same time period, but some differences are also observed (e.g., TM-06 and 13). Considering that the studied collection has a local character, we decided to group the fragments in three sets corresponding to the same age interval. The collection therefore comprises three groups with distinct ages. The different fragments of each group were considered together for deriving the group-mean intensities for each set. Mean intensities (relocated to Paris through the VADM) of $80.2 \pm 5.7 \mu \mathrm{T}, 88.5 \pm 6.0 \mu \mathrm{T}$ and $84.8 \pm 7.2 \mu \mathrm{T}$ were obtained for ages ranging from 750 to $800 \mathrm{AD}$, from 775 to $800 \mathrm{AD}$ and from 800 to 900 $A D$, respectively (Table 2 ).

Supplementary material: Table S3 also shows the results obtained at specimen level for the French sites. Samples from the same site are generally very consistent (e.g., site 36137A). However, important differences are observed between some samples of the same site (e.g., 49007I-9BB and 249B). This highlights the need to study several samples per site in order to recover accurate mean intensities. Between four and 37 samples were used to determine the mean intensities. The means were calculated considering the weighting factor proposed by Prévot et al. (1985). Intensity values between $66.5 \pm 5.4 \mu \mathrm{T}$ and $90.5 \pm 8.7 \mu \mathrm{T}$ (relocated to the latitude of Paris) were obtained for ages ranging from 335 to $1260 \mathrm{AD}$ (Table 2).

Table 2

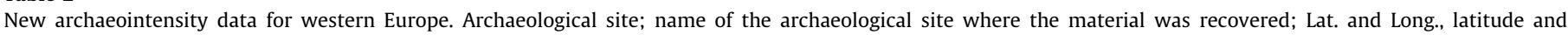

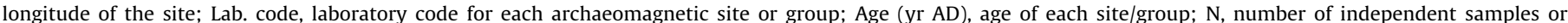

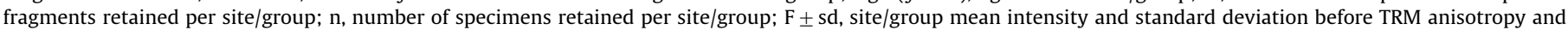

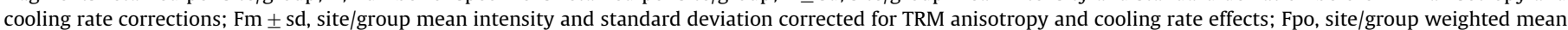
intensity; Fpa, site/group weighted mean intensity relocated to Paris; VADM, values of the virtual axial dipole moment.

\begin{tabular}{|c|c|c|c|c|c|c|c|c|c|c|c|}
\hline Archaeological Site & $\begin{array}{l}\text { Lat. } \\
\text { (deg.) }\end{array}$ & $\begin{array}{l}\text { Long. } \\
\text { (deg.) }\end{array}$ & Lab. code & $\begin{array}{l}\text { Age } \\
\text { (yr AD) }\end{array}$ & $N$ & $n$ & $\begin{array}{l}\mathbf{F} \pm \mathbf{s d} \\
(\mu \mathrm{T})\end{array}$ & $\begin{array}{l}\mathbf{F m} \pm \mathbf{s d} \\
(\mu \mathrm{T})\end{array}$ & $\begin{array}{l}\text { Fpo } \\
(\mu \mathrm{T})\end{array}$ & $\begin{array}{l}\text { Fpa } \\
(\mu \mathrm{T})\end{array}$ & $\begin{array}{l}\text { VADM } \\
\left(10^{22} \mathrm{Am}^{2)}\right.\end{array}$ \\
\hline Clermont l'Hérault & $43.63 \mathrm{~N}$ & $3.43 \mathrm{E}$ & $34079 C$ & {$[335,540]$} & 4 & 4 & $71.1 \pm 7.5$ & $64.1 \pm 3.2$ & 65.6 & 69.2 & 10.9 \\
\hline Pierrefitte-sur-Sauldre & $47.52 \mathrm{~N}$ & $2.10 \mathrm{E}$ & $41176-9$ & {$[590,655]$} & 6 & 8 & $96.5 \pm 9.7$ & $88.6 \pm 8.7$ & 89.3 & 90.5 & 14.2 \\
\hline Néons-sur-Creuse & $46.74 \mathrm{~N}$ & $0.91 \mathrm{E}$ & $36137 A$ & {$[600,900]$} & 5 & 7 & $77.9 \pm 4.0$ & $66.0 \pm 3.7$ & 65.7 & 67.1 & 10.6 \\
\hline Saran, Zac des Vergers & $47.95 \mathrm{~N}$ & $1.88 \mathrm{E}$ & $45302 \mathrm{~A}$ & {$[675,725]$} & 9 & 9 & $81.4 \pm 4.7$ & $77.6 \pm 8.3$ & 79.9 & 80.6 & 12.7 \\
\hline Albacete, Tolmo de Minateda & $38.48 \mathrm{~N}$ & $1.61 \mathrm{~W}$ & $\begin{array}{l}\text { TM-03+TM-06 } \\
+ \text { TM-07+TM-09 }\end{array}$ & {$[750,800]$} & 4 & 11 & $58.4 \pm 11.8$ & $68.2 \pm 5.7$ & 68.3 & 80.2 & 12.0 \\
\hline Albacete, Tolmo de Minateda & $38.48 \mathrm{~N}$ & $1.61 \mathrm{~W}$ & TM-04 + TM-13 & {$[775,800]$} & 2 & 6 & $81.8 \pm 2.5$ & $75.2 \pm 6.0$ & 75.4 & 88.5 & 13.3 \\
\hline Albacete, Tolmo de Minateda & $38.48 \mathrm{~N}$ & $1.61 \mathrm{~W}$ & $\mathrm{TM}-02+\mathrm{TM}-14$ & {$[800,900]$} & 2 & 6 & $60.8 \pm 1.4$ & $72.3 \pm 7.2$ & 72.3 & 84.8 & 12.7 \\
\hline Angers, Collegial church St. Martin & $47.47 \mathrm{~N}$ & $0.55 \mathrm{~W}$ & $49007 \mathrm{I}$ & {$[810,910]$} & 23 & 23 & $77.8 \pm 8.0$ & $80.4 \pm 10.8$ & 81.3 & 82.4 & 13.0 \\
\hline $\begin{array}{l}\text { Mont-Sain- Michel, Notre-Dame-Sous- } \\
\text { Terre church }\end{array}$ & $48.63 \mathrm{~N}$ & $1.50 \mathrm{~W}$ & 50353 & {$[900,990]$} & 37 & 37 & $70.0 \pm 9.7$ & $68.8 \pm 7.0$ & 69.9 & 70.1 & 11.0 \\
\hline Avranches, Castle of Avranches & $48.68 \mathrm{~N}$ & $1.35 \mathrm{~W}$ & $50025 \mathrm{~A}$ & {$[1100,1260]$} & 10 & 10 & $69.9 \pm 6.7$ & $66.5 \pm 5.4$ & 66.4 & 66.5 & 10.5 \\
\hline
\end{tabular}


Ten new archaeointensities were obtained using one of the more reliable methods (Thellier and Thellier, 1959) including TRM anisotropy and cooling rate corrections. They were derived from the analysis of several specimens per pottery fragment and several fragments per age interval or several independent samples per structure/building. Consistent values were obtained from the different materials studied: bricks, kilns and pottery fragments (Fig. 7a). For example, the results obtained for the 9th century from the ceramic fragments and bricks are very similar (84.8 $\mu \mathrm{T}$ and $82.4 \mu \mathrm{T}$, respectively). Therefore, we consider the new data as reliable markers of past geomagnetic field intensity in western Europe. As expected, the virtual axial dipole moment

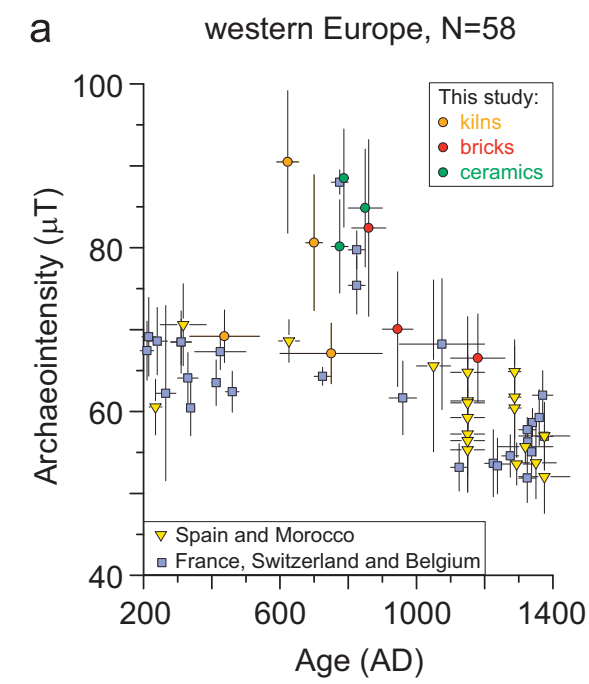

b eastern Europe, $\mathrm{N}=42$
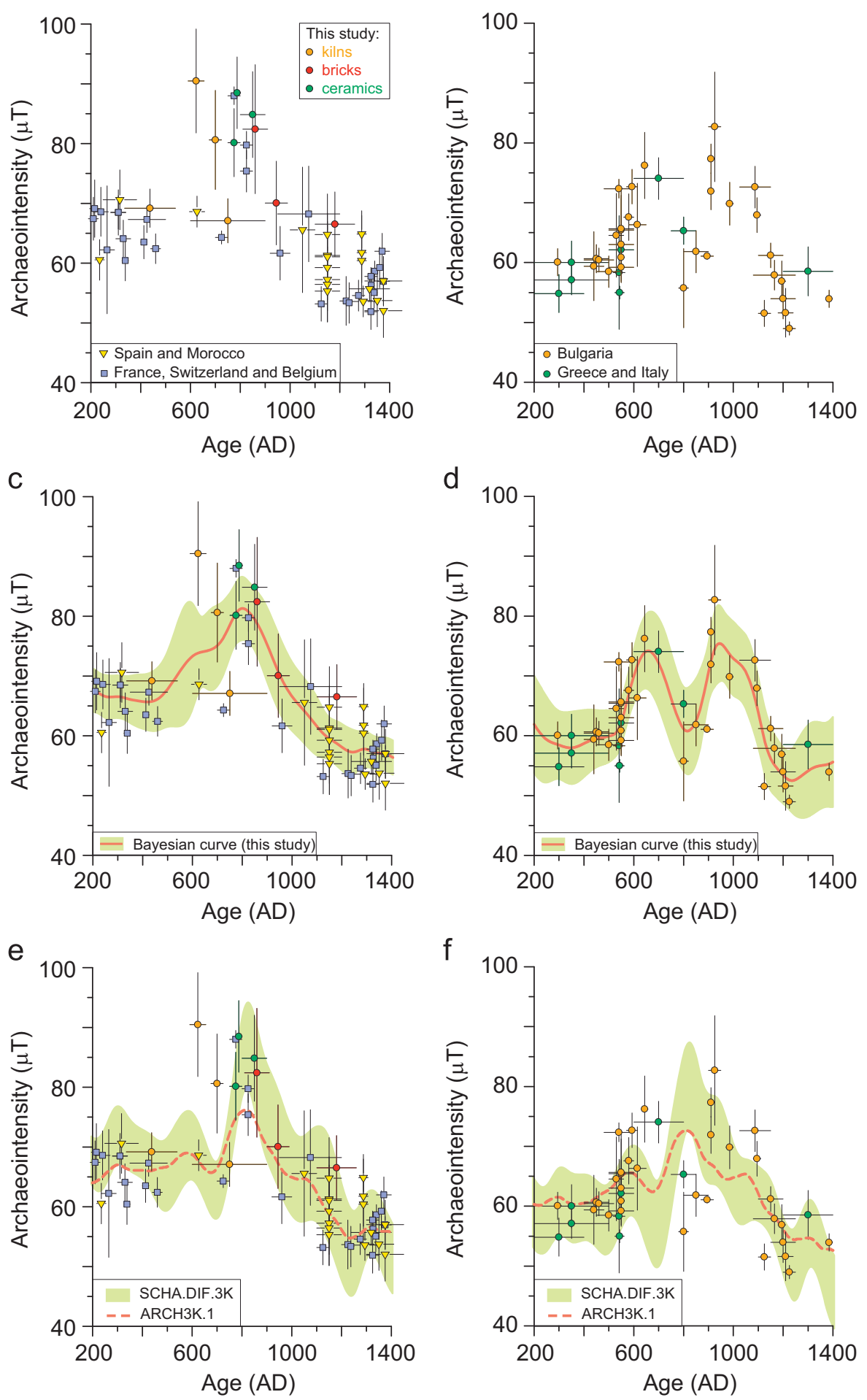

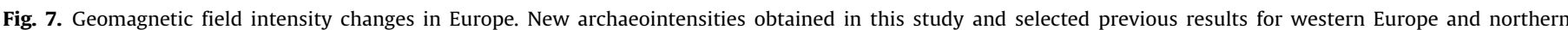

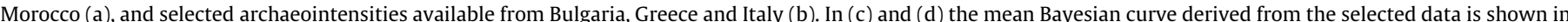

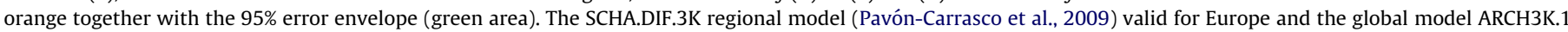

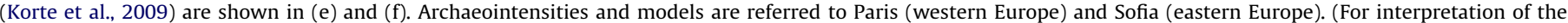
references to color in this figure legend, the reader is referred to the web version of this article.) 
(VADM) results obtained from the 8th to the 10th centuries (Table 2) are higher than the present-day dipole field value (Genevey and Gallet, 2002).

\subsection{Geomagnetic field intensity changes in western Europe between 200 and $1400 A D$}

In order to analyse geomagnetic field intensity changes in western Europe between 200 and 1400 AD previously published archaeointensities for Spain, France and nearby countries have been selected. As discussed by Chauvin et al. (2000) and Genevey et al. (2008) not all the archaeointensity data can be regarded as equally reliable. Therefore, we consider only high-quality archaeointensities obtained from Thellier or Thellier-derived experiments including pTRM checks during laboratory experiments. Only 48 archaeointensities from western Europe and nearby countries pass this selection criterion. The selection includes data from France $(N=26$, Chauvin et al., 2000; Gallet et al., 2009a; Genevey and Gallet, 2002; Genevey et al., 2009), Spain $(N=18$, Catanzariti et al., 2012; Gómez-Paccard et al., 2006c, 2008), Switzerland $(N=1$, Donadini et al., 2008; Kovacheva et al., 2009a), Belgium ( $N=2$, Genevey et al., 2009; Spassov et al., 2008) and northern Morocco ( $N=1$, Gómez-Paccard et al., 2012). All data have been relocated to the latitude of Paris through the VADM (Fig. 7a).

The 48 selected data together with the new archaeointensities obtained in this study enable an improved description of geomagnetic intensity changes that took place in western Europe between the 3rd and the 14th centuries AD. The pattern of archaeointensities indicates approximately constant values between 300 and $500 \mathrm{AD}$ (around $65 \mu \mathrm{T}$ ) followed by an increase up to $\sim 90 \mu \mathrm{T}$ around $600 \mathrm{AD}$ (new data of site 41176-9). However, the archaeointensity, recently obtained by Catanzariti et al. (2012) for similar ages, is not in agreement with this and gives a much lower value (yellow triangle in Fig. 7a). There are two possible explanations for the observed offset. The first is that the Earth's magnetic field varied very quickly in a very short interval of time, and the second is that these sites are not accurately dated. With the available information we cannot consider one of these hypotheses to be more plausible than the other. Our new data (sites 41176-9, 45302A and 36137A, orange circles in Fig. 7) do however suggest that an important decrease of the Earth's magnetic field intensity occurred between 600 and $750 \mathrm{AD}$ which is also supported by previously published data (blue square, Fig. 7a). High intensities (of about $85 \mu \mathrm{T}$ ) are reached again very quickly around $800-850 \mathrm{AD}$. The occurrence of this maximum is now supported by seven archaeointensities (four obtained here and three previously published, Fig. 7a). A global trend of intensity decrease (better described now due to the new data of site 50353) is observed between $800 \mathrm{AD}$ and 1400 AD. However, the data suggest that field strength is still high $(\sim 65 \mu \mathrm{T})$ around $1150 \mathrm{AD}$ (confirmed by the new result of site $50025 \mathrm{~A}$ ) and that an intensity peak occurred around $1300 \mathrm{AD}$ (described from three well-dated archaeointensities from central Spain (Gómez-Paccard et al., 2008)).

The western European archaeointensities (Fig. 7a) indicate that abrupt geomagnetic field intensity changes took place in this region during the last millennia. If we consider mean intensities and ages described in Table 2, intensity changes as fast as 18 and $12 \mu \mathrm{T} /$ century are obtained between $622.5 \mathrm{AD}$ (site 41176-9) and $750 \mathrm{AD}$ (site 36137A) and between 787.5 AD (site TM-04+TM13 ) and $945 \mathrm{AD}$ (site 50353), respectively. Higher rates of change, of about $50 \mu \mathrm{T} /$ century, are obtained from mean values of sites 36137A (750 AD) and TM-03+06+07+09 (775 AD). Differences between the mean values available for the 12th century AD indicate a rapid intensity change of $\sim 25 \mu \mathrm{T} /$ century (Fig. 7a).
Finally, an extreme variation of geomagnetic field strength of $\sim 80 \mu \mathrm{T} /$ century during the second half of the 13th century AD is deduced from sites A08 (Genevey and Gallet, 2002) and CALA (Gómez-Paccard et al., 2008). This rate is calculated from data obtained from Thellier derived experiments including pTRM checks and TRM anisotropy and cooling rate corrections from the study of very well dated potsherds (A08, $1275 \pm 25$ AD) and one archaeological kiln abandoned between 1275 and $1300 \mathrm{AD}$ (CALA). We must notice, however, that age uncertainties and errors on intensity estimations can affect considerably the calculated rates of change. For example, if we consider the minimum possible age for site A08 and the maximum for CALA, a lower rate of $20 \mu \mathrm{T} /$ century is obtained. Nevertheless, the results indicate that the rates of intensity changes that took place in western Europe during the last millennia are much higher than has been previously described (about $7 \mu \mathrm{T}$ per century) (Genevey and Gallet, 2002; Genevey et al., 2009). However, they are lower than the rates of change of more than $100 \mu \mathrm{T} /$ century described by Shaar et al. (2011) from Iron Age copper slag deposits from Israel.

The Bayesian approach (Lanos 2004; Lanos et al., 2005) has been applied to calculate the geomagnetic field intensity PSV curve using the aforementioned dataset (Fig. 7c). The low number of data available between 500 and $1000 \mathrm{AD}$ and the offset between the two intensities available around $600 \mathrm{AD}$ are clearly reflected in the results obtained. The Bayesian curve presented here must be, therefore, considered as a preliminary result. Future improvements in the number of well-dated source data (especially for the period 500-800 AD and for ages around 1150 and $1300 \mathrm{AD}$ ) will allow a robust description of geomagnetic field intensity variations and of the rates of intensity change and, therefore, will improve our knowledge of geomagnetic field behaviour.

\subsection{Geomagnetic field intensity changes in eastern Europe between 200 and $1400 A D$}

In order to investigate if the intensity maxima observed in western Europe are seen at a continental scale we have selected high-quality archaeointensities from Bulgaria, Italy and Greece with ages ranging from 200 to 1400 AD. As for western Europe only data derived from Thellier derived experiments and including pTRM checks have been retained. A total of 42 data from Bulgaria $(N=33$, Kovacheva et al., 2009a), Greece $(N=6$, De Marco et al., 2008; Spatharas et al., 2000, 2011; Tema et al., 2012) and Italy ( $N=3$; Leonhardt et al., 2006; Tema et al., 2010) have been selected and relocated to the latitude of Sofia through the VADM (Fig. 7b). The selected data and the derived Bayesian curve (Fig. 7d) indicate very similar intensity changes to those observed in western Europe, with the occurrence of two intensity bumps (up to $\sim 75 \mu \mathrm{T}$ ) at ages around 650 and $950 \mathrm{AD}$. The results also suggest the occurrence of two periods of rapid intensity changes between 1100 and $1200 \mathrm{AD}$ and around $1300 \mathrm{AD}$. The results indicate that extreme intensity variation as fast as $20 \mu \mathrm{T}$ per century occurred in eastern Europe during historical times (Fig. 7b). The intensity pattern described (Fig. 7b and d) is similar to the one obtained from Bulgarian data using a different technique for computation of the mean intensity curve (see Fig. 10, Genevey et al., 2003).

It must be underlined that the two independent local datasets treated (western and eastern Europe) show very similar features with (probably) two maxima around 600-650 AD, 800-950 AD, and two abrupt geomagnetic field intensity changes during the 12 th century $\mathrm{AD}$ and around the second half of the 13th century AD (Fig. 7a-d). This indicates that these sharp geomagnetic field intensity changes occurred at the continental scale. The sharp increase that took place in Europe around 800-950 AD is well 
documented in both areas whereas the occurrence of a sharp intensity peak around 600-650 AD must be confirmed for western Europe (it is only described by one data). Finally, the rapid intensity variation that probably took place in eastern Europe during the second half of the 13 th century AD needs also to be confirmed.

The occurrence of a double oscillation of geomagnetic field intensity in Europe has previously been suggested by Pesonen and Leino (1998) from the study of Finish archaeointensity data (with the two intensity maxima centred at $\sim 500$ and $\sim 800$ AD), suggesting that the double oscillation described here is also observed at more northerly latitudes.

Finally, the western and the eastern selected data were compared with SCHA.DIF.3k regional (Pavón-Carrasco et al., 2009) and ARCH3 K.1 global (Korte et al., 2009) geomagnetic field models (Fig. 7e and f). The SCHA.DIF.3K model results are in close agreement with the western European data (except for the new data obtained around $600 \mathrm{AD}$ ) but do not reproduce well the eastern European dataset. This regional model also suggests the occurrence of relative minor intensity maxima around $600 \mathrm{AD}$. The ARCH3K.1 global model seems to reproduce similar variations to those predicted by the regional model but gives lower intensities for the period of high intensities observed in western Europe around $800 \mathrm{AD}$ (Fig. 7e). Compared with the eastern European data both models do not fit well the two periods of high intensities observed (Fig. 7f). It is worth noting that these models are based on all the available archaeointensity data without any pre-selection based on their reliability. Therefore, model results may be affected by some inaccurate data presented in the databases. In our opinion, these results indicate that a selection of archaeointensity data, based on the technique used for archeointensity determination, should be performed if a higher resolution description of geomagnetic field intensity changes is to be obtained.

\section{Conclusion}

Ten high-quality archaeointensities from the study of 13 precisely dated early medieval Spanish pottery fragments, four French kilns and three collections of bricks used for the construction of French historical buildings with ages ranging between 335 and $1260 \mathrm{AD}$ have been obtained. The new intensities - corrected for TRM anisotropy and cooling rate effects - can be considered as reliable markers of past geomagnetic field intensity. Together with a selection of the previous data that we deem to be the most reliable for western Europe, they enable an improved description of geomagnetic field intensity changes that took place in this region between the $3 \mathrm{rd}$ and the 14th centuries $\mathrm{AD}$. The results confirm that an intensity maximum of $\sim 85 \mu \mathrm{T}$ (at the latitude of Paris) occurred in western Europe at around $800 \mathrm{AD}$ and suggest that a previous abrupt intensity change took place around $600 \mathrm{AD}$. Western European data also suggest the occurrence of abrupt geomagnetic field intensity changes during the 12 th century AD and around the second half of the 13th century AD. Reliable selected eastern European data show a similar variation of geomagnetic field intensity with the occurrence of two intensity bumps (up to $\sim 75 \mu \mathrm{T}$ at the latitude of Sofia) at ages around 650 and $950 \mathrm{AD}$ and two periods of rapid intensity changes during the 12 th century $\mathrm{AD}$ and $\sim 1300 \mathrm{AD}$. The results suggest that the described features of the geomagnetic field are observed at a continental scale and that very rapid intensity changes (of at least of $20 \mu \mathrm{T}$ /century) took place in the recent history of the Earth's magnetic field. The results call for additional precisely dated archaeointensities and for a selection of high-quality data, for obtaining a refined path of the evolution of the Earth's magnetic field intensity at regional scales.

\section{Acknowledgements}

Financial support was given by a CSIC JAE-Doc contract (MGP), by the Nos. CGL2008-02203/BTE, CGL2011-24790, and CGL2010$15767 /$ BTE projects from the Spanish ministry of Science and Innovation, the Complutense University, the Comunidad de Madrid Consolidación de grupos program (No. 910396), and by the Junta de Comunidades de Castilla-La-Mancha. M.K. acknowledges Géosciences-Rennes (Université de Rennes 1), where she has spent two months working at the palaeomagnetic laboratory. We thank the editor and one anonymous referee for their valuable comments that greatly improved this paper. The authors acknowledge their European ancestors for their pottery, bricks and kilns manufacture.

\section{Appendix A. Supporting information}

Supplementary data associated with this article can be found in the online version at http://dx.doi.org/10.1016/j.epsl.2012.08.037.

\section{References}

Bard, E., Delaygue, G., 2008. Comment on "Are there connections between the Earth's magnetic field and climate?" by V. Courtillot et al. [Earth and Planetary Science Letters, 253, 328, 2007]. Earth Planet. Sci. Lett. 265, 302-307, http://dx .doi.org/10.1016/j.epsl.2007.09.046.

Biggin, A.J., 2010. Are systematic differences between thermal and microwave Thellier-type palaeointensity estimates a consequence of multidomain bias in the thermal results? Phys. Earth Planet. Inter. 180, 16-40, http://dx.doi.org/ 10.1016/j.pepi.2010.03.005

Catanzariti, G., Gómez-Paccard, M., McIntosh, G., Pavón-Carrasco, F.J., Chauvin, A., Osete, M.L., 2012. New archaeomagnetic data recovered from the study of Roman and Visigothic remains from central Spain (3rd-7th centuries). Geophys. J. Int 188, 979-993, http://dx.doi.org/10.1111/j.1365-246X.2011.05315.x.

Chauvin, A., Garcia, Y., Lanos, P., Laubenheimer, F., 2000. Paleointensity of the geomagnetic field recovered on archaeomagnetic sites from France. Phys. Earth Planet. Inter. 120, 111-136.

Coe, R.S., 1967. The determination of paleointensities of Earth's magnetic field with emphasis on mechanisms which could cause non ideal behavior in Thellier's method. J. Geomagn Geoelectr. 19, 157-180.

Coe, R.S., Grommé, C.S., Mankinen, E.A., 1978. Geomagnetic paleointensities from radiocarbon-dated lava flows on Hawaii and the question of the Pacific nondipole low. J. Geophys. Res. 83, 1740-1756.

Courtillot, V., Gallet, Y., Le Mouel, J.L., Fluteau, F., Genevey, A., 2007. Are there connections between the Earth's magnetic field and climate? Earth Planet. Sci. Lett. 253, 328-339, http://dx.doi.org/10.1016/j.epsl.2006.10.032.

De Marco, E., Spatharas, V., Gómez-Paccard, M., Chauvin, A., Kondopoulou, D. 2008. New archaeointensity results from archaeological sites and variation of the geomagnetic field intensity for the last 7 millennia in Greece. Phys. Chem. Earth 33, 578-595, http://dx.doi.org/10.1016/j.pce.2008.02.025.

Donadini, F., Kovacheva, M., Kostadinova, M., Hedley, I.G., Pesonen, L.J., 2008 Palaeointensity determination on an early medieval kiln from Switzerland and the effect of cooling rate. Phys. Chem. Earth 33, 449-457, http://dx.doi.org/ 10.1016/j.pce.2008.02.019.

Finlay, C.C., 2008. Historical variation of the geomagnetic axial dipole. Phys. Earth Planet. Inter. 170, 1-14, http://dx.doi.org/10.1016/j.pepi.2008.06.029.

Fisher, R.A., 1953. Dispersion on a sphere. Proc. R. Soc. London A 217, 295

Gallet, Y., Genevey, A., Le Goff, M., 2002. Three millennia of directional variation of the Earth's magnetic field in Western Europe as revealed by archaeological artefacts. Phys. Earth Planet. Inter. 131, 81-89.

Gallet, Y., Genevey, A., Courtillot, V., 2003. On the possible occurrence of archaeomagnetic jerks in the geomagnetic field over the past three millennia. Earth Planet. Sci. Lett. 214, 237-242.

Gallet, Y., Genevey, A., Fluteau, F., 2005. Does Earth's magnetic field secular variation control centennial climate change? Earth Planet. Sci. Lett. 236 339-347

Gallet, Y., Genevey, A., Le Goff, M., Warmé, N., Gran-Aymerich, J., Lefevre, A., 2009a. On the use of archeology in geomagnetism, and vice-versa: recent developments in archeomagnetism. C. R. Phys. 10, 630-648.

Gallet, Y., Hulot, G., Chulliat, A., Genevey, A., 2009b. Geomagnetic field hemispheric asymmmetry and archeomagnetic jerks. Earth Planet. Sci. Lett. 284 (12), 179-186, http://dx.doi.org/10.1016/J.EPSL.2009.04.28. 
Genevey, A., Gallet, Y., 2002. Intensity of the geomagnetic field in western Europe over the past 2000 years: new data from ancient French pottery. J. Geophys. Res. 107, 2285, http://dx.doi.org/10.1029/2001JB000701.

Genevey, A., Gallet, Y., Margueron, 2003. Eight thousand years of geomagnetic field intensity variations in the eastern Mediterranean. J. Geophys. Res. 108, 228, ht tp://dx.doi.org/10.1029/2001JB001612.

Genevey, A., Gallet, Y., Constable, C.G., Korte, M., Hulot, G., 2008. ArcheoInt: an upgraded compilation of geomagnetic field intensity data for the past ten millennia and its application to the recovery of the past dipole moment Geochem. Geophys. Geosyst. 9 (4), Q04038, http://dx.doi.org/10.1029/ 2007GC001881.

Genevey, A., Gallet, Y., Rosen, J., Le Goff, M., 2009. Evidence for rapid geomagnetic field intensity variations in Western Europe over the past 800 years from new French archeointensity data. Earth Planet. Sci. Lett. 284, 132-143, http://dx.do i.org/10.1016/j.epsl.2009.04.024.

Gilks, W.R., Richardson, S., Spiegelhalter, D.J., 1996. Markov Chain Monte Carlo in Practice, Interdisciplinary Statistics. Chapman and Hall, London.

Gómez-Paccard, M., Catanzariti, G., Ruiz-Martinez, V.C., McIntosh, G., Núñez, J.I., Osete, M.L., Chauvin, A., Lanos, P., Tarling, D.H., Bernal-Casasola, D., Thiriot, J. Archaeological Working group, 2006a. A catalogue of Spanish archaeomagnetic data. Geophys. J. Int. 166, 1125-1143, http://dx.doi.org/10.1111/j.1365246X.2006.03020.x.

Gómez-Paccard, M., Chauvin, A., Lanos, P., McIntosh, G., Osete, M.L., Catanzariti, G. Ruiz-Martinez, V.C., Núñez, J.I., 2006b. First archaeomagnetic secular variation curve for the Iberian Peninsula: comparison with other data from western Europe and with global geomagnetic field models. Geochem. Geophys. Geosyst. 7, 012001, http://dx.doi.org/10.1029/2006GC001476.

Gómez-Paccard, M., Chauvin, A., Lanos, P., Thiriot, J., Jimenez-Castillo, P., 2006c Archeomagnetic study of seven contemporaneous kilns from Murcia (Spain). Phys. Earth Planet. Inter. 157, 16-32, http://dx.doi.org/10.1016/j.pepi.2006. 03.001 .

Gómez-Paccard, M., Chauvin, A., Lanos, P., Thiriot, J., 2008. New archeointensity data from Spain and the geomagnetic dipole moment in western Europe ove the past 2000 years. J. Geophys. Res. 113, B09103, http://dx.doi.org/10.1029/ 2008JB005582.

Gómez-Paccard, M., McIntosh, G., Chauvin, A., Beamud, E., Carrasco, F.J., Thiriot, J. 2012. Archaeomagnetic and rock magnetic study of six kilns from North Afric (Tunisia and Morocco). Geophys. J. Int. 189, 169-186, http://dx.doi.org/ 10.1111/j.1365-246X.2011.05335.x.

Gubbins, D., Jones, A.L., Finlay, C.C., 2006. Fall in Earth's magnetic field is erratic Science 312, 900-902, http://dx.doi.org/10.1126/science.1124855.

Hartmann, G.A., Genevey, A., Gallet, Y., Trindade, R.I.F., Le Goff, M., Najjar, R., Etchevarne, C., Afonso, M.C., 2011. New historical archeointensity data from Brazil: evidence for a large regional non-dipole field contribution over the pas few centuries. Earth Planet. Sci. Lett. 306, 66-76, http://dx.doi.org/10.1016/ j.epsl.2011.03.030.

Hervé, G., Schnepp, E., Chauvin, A., Lanos, P., Nowaczyck, N., 2011. Archaeomagnetic results on three Early Iron Age salt-kilns from Moyenvic (France). Geophys. J. Int 185, 144-156, http://dx.doi.org/10.1111/j.1365-246X.2011.01933.x.

Jackson, A., Jonkers, A.R.T., Walker, M.R., 2000. Four centuries of geomagnetic secular variation from historical records. Philos. Trans. R. Soc. London, A 358 (1768), 957-990, http://dx.doi.org/10.1098/rsta.2000.0569.

Kirschvink, J.L., 1980. The least-squares line and plane and the analysis of paleomagnetic data. Geophys. J. R. Astron. Soc. 62, 699-718.

Korte, M., Donadini, F., Constable, C.G., 2009. Geomagnetic field for 0-3 ka: 2. A new series of time-varying global models. Geochem. Geophys. Geosyst. 10, Q06008, http://dx.doi.org/10.1029/2008GC002297.

Kovacheva, M., Boyadziev, Y., Kostadinova-Avramova, M., Jordanova, N., Donadini, F., 2009a. Updated archeomagnetic data set of the past 8 millennia from the Sofia laboratory, Bulgaria. Geochem. Geophys. Geosyst. 10, Q05002, http://dx doi.org/10.1029/2008GC002347.

Kovacheva, M., Chauvin, A., Jordanova, N., Lanos, P., Karloukovski, V., 2009b. Remanence anisotropy effect on the palaeointensity results obtained from various archaeological materials, excluding pottery. Earth Planets Space 61, 711-732.

Lanos, P., 2001. L'approche bayésienne en chronométrie: application à l'archéomagnétisme. In: Barrandon, J.N., Guibert, P., Michel, V. (Eds.), Datation, XXIe rencontres internationales d'archéologie et d'histoire d'Antibes. éditions APDCA, Antibes, pp. 113-139.

Lanos, P., 2004. Bayesian inference of calibration curves: application to archaeomagnetism. In: Buck, C.E., Millard, A.R. (Eds.), Tools for Constructing Chronologies: Crossing Disciplinary Boundaries. Lecture Notes in Statistics. Springer, London, pp. 43-82.

Lanos, P., Le Goff, M., Kovacheva, M., Schnepp, E., 2005. Hierarchical modeling of archaeomagnetic data and curve estimation by moving average technique. Geophys. J. Int. 160, 440-476.
Leonhardt, R., Matzka, J., Nichols, A.R.L., Dingwell, D.B., 2006. Cooling rate correction for paleointensity determination for volcanic glasses by relaxation geospeedometry. Earth Planet. Sci. Lett. 243, 282-292, http://dx.doi.org/ 10.1016/j.epsl.2005.12.038.

Márton, P., 2010. Two thousand years of geomagnetic field direction over central Europe revealed by indirect measurements. Geophys. J. Int. 181, 261-268.

Muscheler, R., Joos, F., Beer, J., Muller, S.A., VonMoos, M., Snowball, I., 2007. Solar activity during the last $1000 \mathrm{yr}$ inferred from radionuclide records. Q. Sci. Rev. 26, 82-97.

Pavón-Carrasco, F.J., Osete, M.L., Torta, J.M., Gaya-Pique, L.R., 2009. A regional archeomagnetic model for Europe for the last 3000 years, SCHA.DIF.3K: applications to archeomagnetic dating. Geochem. Geophys. Geosyst. 10 (22), Q03013, http://dx.doi.org/10.1029/2008GC002244.

Pesonen, L.J., Leino, A.H., 1998. Archaeomagnetic intensity in Finland and Bulgaria-problems in the applied technique or evidence of a non-dipole field? Phys. Chem. Earth 23, 1021-1025.

Pick, T., Tauxe, L., 1993. Holocene paleointensities: Thellier experiments on submarine basaltic glass from the East Pacific Rise. J. Geophys. Res. 98, 17949-17964.

Prévot, M., Mankinen, E.A., Coe, R.S., Grommé, C.S., 1985. The Steens Mountain (Oregon) geomagnetic polarity transition. 2. Field intensity variations and discussion of reversal models. J. Geophys. Res. 90, 10417-10448.

RenDateModel, Lanos, P., Dufresne, P., 〈http://www.projet-plume.org/fr/relier/ rendatemodel $>$.

Sapin, C., Baylé, M., Büttner, S., Gibert, P., Blain, S., Lanos, P., Chauvin, A., Dufresne, P., Oberlin, C., 2008. Archéologie du bâti et archéométrie au Mont-SaintMichel, nouvelles approches de Notre-Dame-Sous-Terre. Archéologie Médiévale $38,71-122$

Schnepp, E., Lanos, P., 2005. Archaeomagnetic secular variation in Germany during the past 2500 years. Geophys. J. Int. 163, 479-490.

Schnepp, E., Lanos, P., Chauvin, A., 2009. Geomagnetic paleointensity between 1300 and 1750 A.D. derived from a bread oven floor sequence in Lübeck, Germany. Geochem. Geophys. Geosyst. 10, Q08003, http://dx.doi.org/10.1029/ 2009GC002470.

Shaar, R., Ben-Yosef, E., Ron, H., Tauxe, L., Agnon, A., Kessel, R., 2011. Geomagnetic field intensity: how high can it get? How fast can it change? Constraints from Iron Age copper slag. Earth Planet. Sci. Lett. 301, 297-306.

Shcherbakova, V.V., Shcherbakov, V.P., Heider, F., 2000. Properties of partial thermoremanent magnetization in PSD and MD magnetite grains. J. Geophys. Res. 105, 767-781.

Snowball, I., Muscheler, R., 2007. Palaeomagnetic intensity data: an Achilles heel of solar activity reconstructions. Holocene 17, 851-859.

Spassov, S., Hus, J., Geeraerst, R., Heller, F., 2008. Archaeomagnetic dating of a High Middle Age likely iron working site in Corroy-le-Grand (Belgium). Phys. Chem. Earth 33, 544-556.

Spatharas, V., Kondopoulou, D., Liritzis, I., Tsokas, G.N., 2000. Archaeointensity results from two ceramic kilns from N. Greece. J. Balkan Geophys. Soc 3, 67-72.

Spatharas, V., Kondopoulou, D., Aidona, E., Efthimiadis, K.G., 2011. New magnetic mineralogy and archaeointensity results from Greek kilns and baked clays. Stud. Geophys. Geod. 55, 131-157.

Stark, F., Cassidy, J., Hill, M., Shaw, J., Sheppard, P., 2010. Establishing a first archeointensity record for the SW Pacific. Earth. Planet. Sci. Lett. 298, 113-124.

Suttie, N., Holme, R., Hill, M.J., Shaw, J., 2011. Consistent treatment of errors in archaeointensity implies rapid decay of the dipole prior to 1840. Earth Planet. Sci. Lett. 304, 13-21.

Tema, E., Hedley, I., Lanos, P., 2006. Archaeomagnetism in Italy: a compilation of data including new results and a preliminary Italian secular variation curve. Geophys. J. Int. 167, 1160-1171.

Tema, E., Goguitchaichvili, A., Camps, P., 2010. Archaeointensity determinations from Italy: new data and the Earth's magnetic field strength variation over the past three millennia. Geophys. J. Int. 180, 596-608, http://dx.doi.org/10.1111/ j.1365-246X.2009.04455.x.

Tema, E., Gómez-Paccard, M., Kondopoulou, D., Almar, Y., 2012. Intensity of the Earth's magnetic field in Greece during the last five millennia: new data from Greek pottery. Phys. Earth Planet. Inter. 202-203, 14-26, http://dx.doi.org/ 10.1016/j.pepi.2012.01.012.

Thellier, E., Thellier, O., 1959. Sur l'intensité du champ magnétique terrestre dans le passé historique et géologique. Ann. Géophys. 15, 285-376.

Wollin, G., Ericson, D.B., Ryan, W.B.F., 1978. Climatic changes, magnetic intensity variations and fluctuations of eccentricity of Earth's orbit during past $2,000,000$ years and mechanism which may be responsible for relationship. Earth Planet. Sci. Lett. 41, 395-397.

Zananiri, I., Batt, C.M., Lanos, P., Tarling, D.H., Linford, P., 2007. Archaeomagnetic secular variation in the UK during the past 4000 years and its application to archaeomagnetic dating. Phys. Earth Planet. Inter. 160, 97-107. 